\title{
Ludowość utracona? Strategie instytucjonalizacji sztuki ludowej w Szkole Przemysłu Drzewnego w Zakopanem
}

DOI: https://doi.org/10.21697/an.9372

MARIA MUSZKOWSKA

VILLA LA FLEUR

ORCID 0000-0002-3289-6812

W procesie przemian percepcji sztuki ludowej dokonującym się na przełomie XIX i XX w. na ziemiach polskich decydującą rolę odegrała zakopiańska Szkoła Przemysłu Drzewnego' (il. 1). Na przestrzeni lat w obrębie placówki skupionej na edukacji rzemieślniczej realizowano różnorodne programy nauczania, w których centralne miejsce zajmowała ludowość. W lokalnym, podhalańskim „prymitywie” ${ }^{2}$ - sztuce nieprofesjonalnej - poszukiwano ożywczej egzotyki, nowego źródła inspiracji, formy

1 W XIX w. na terenie Galicji mianem „przemysłu” określano rękodzieło. Na temat problemów terminologicznych związanych z tym określeniem zob. H. Kenarowa, Od zakopiańskiej Szkoły Przemysłu Drzewnego do szkoły Kenara. Studium z dziejów szkolnictwa zawodowo-artystycznego w Polsce, Kraków 1978, s. 13-14.

2 Szeroko pojęty „prymityw” - definiowany jako sztuka nieprofesjonalna - od końca XIX w. był według wielu artystów nowoczesnych (by wymienić chociaż Paula Gauguina czy Pabla Picassa) źródłem odnowy języka sztuki. Pojęcie to powszechnie pojawiało się w retoryce omawianego okresu, jednak od lat 70. XX w. jest powoli wypierane $\mathrm{z}$ oficjalnego dyskursu o sztuce $\mathrm{z}$ uwagi na swe pejoratywne, protekcjonalne zabarwienie, sugerujące relację podrzędną. Biorąc pod uwagę związane z tym trudności, w poniższej pracy ujmować je będę w cudzysłów. oporu czy alternatywnej perspektywy historycznej, opartej nie na romantycznej wizji klęski, a na mitycznych czasach słowiańskich. Efektem tych poszukiwań była popularyzacja „wyobrażonej” góralszczyzny oraz funkcjonujący w międzywojniu wizerunek Polski jako kraju folkloru.

Niniejsze studium stanowi propozycję krytycznej analizy projektów konstruowania stylów regionalnego i narodowego, opartych na ludowości, realizowanych w programach zakopiańskiej szkoły z lat 1879-1939 (to jest od jej powstania aż do wybuchu II wojny światowej). Ówczesna twórczość rzeźbiarska oraz prowadzona w jej zakresie edukacja ukazują różnorodność prób instytucjonalizacji oraz instrumentalizacji ludowości. W literaturze przedmiotu brak jednak wyczerpującej analizy tego procesu: uwzględniającej perspektywę postkolonialną, uwarunkowania społeczno-polityczne, szczegółową ewolucję programu nauczania Szkoły Przemysłu Drzewnego czy analizę długofalowych skutków podejścia do góralszczyzny³.

3 Zalążek studium analizowanego zagadnienia znaleźć można w: K. Chrudzimska-Uhera, Stylizacje i modernizacje. O rzeźbie i rzeźbiarzach w Zakopanem w latach 1879-1939, Warszawa 2013; A. Szczerski, Cztery nowoczesności. Teksty o sztuce i architekturze polskiej XX wieku, Kraków 2015; M. Stobiecka, Kolonialny 


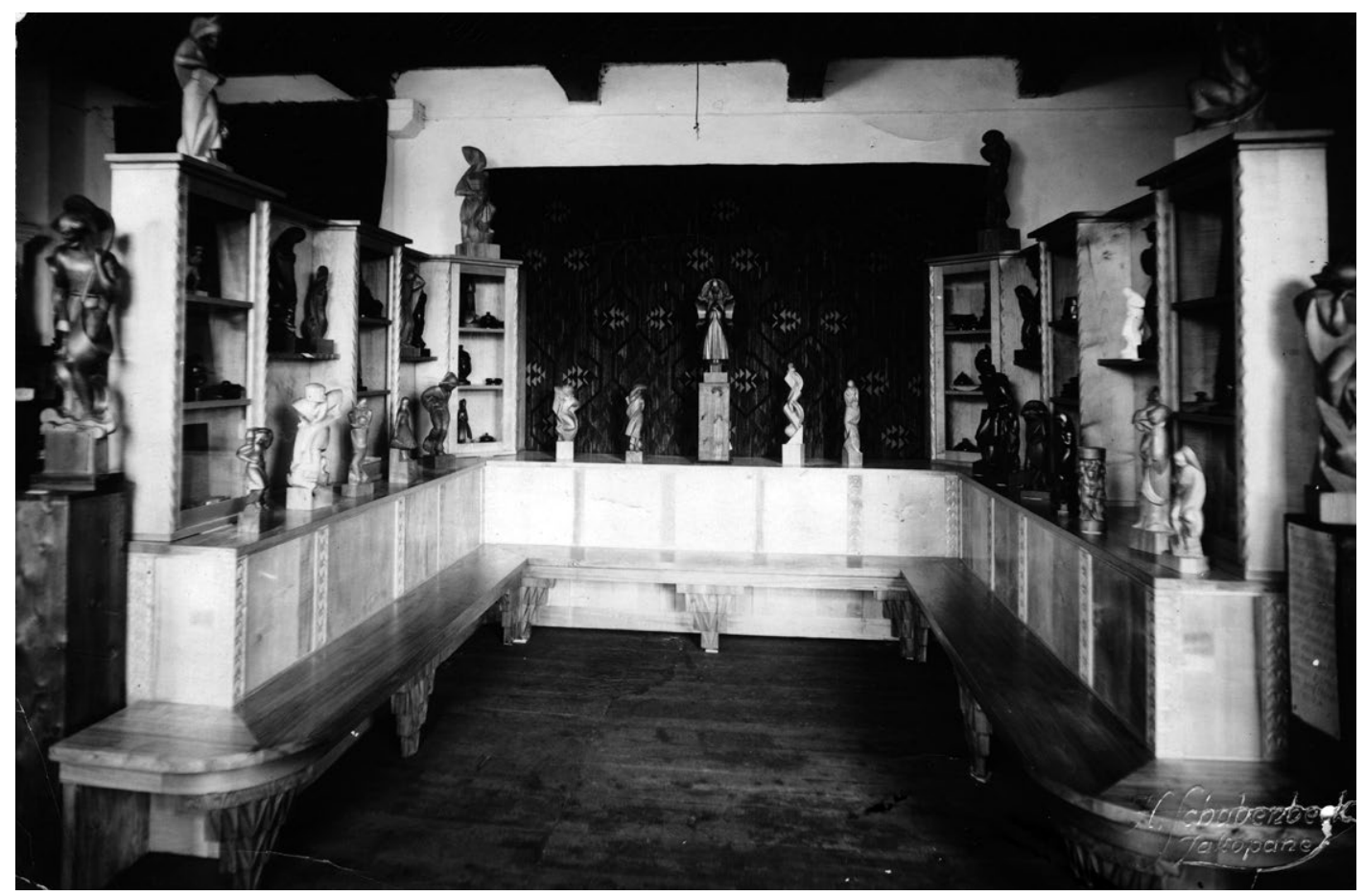

1. Wystawa w Szkole Przemysłu Drzewnego w Zakopanem, 1930 r. Fot. Henryk Schabenbeck, Narodowe Archiwum Cyfrowe

Celem tekstu jest prześledzenie mechanizmów działania szkoły zgodnie z przekonaniem, że to właśnie ta placówka przyczyniła się do przemiany postrzegania ludowości na przestrzeni analizowanego okresu. Metamorfoza ta przebiegła od romantycznej mitologizacji góralskości, która leżała u podstaw stylu zakopiańskiego, aż do zatarcia pierwotnego charakteru lokalnego folkloru wskutek jego zawłaszczenia, nadużywania i ciągłych redefinicji. Zakres studium wyznaczają narzędzia zaczerpnięte $\mathrm{z}$ teorii postkolonialnej oraz nauk społecznych ${ }^{4}$.

Na przełomie XIX i XX w. wpływy ruchu Arts \& Crafts oraz idei romantycznych

regionalizm. Problem tożsamości w zakopiańskiej architekturze, „Miejsce”, 2019, nr 5, https://www.doi. org/10.48285/8kaerzco3p [dostęp 17 I 2021].

4 Studia postkolonialne to zróżnicowana tendencja badawcza, eksploatująca przede wszystkim spektrum problematyki dotyczącej relacji kultura - władza. Zastosowanie perspektywy postkolonialnej w tym tekście zostało spowodowane chęcią wykorzystania kategorii krytycznych szeroko używanych w tym obszarze, między innymi „wyobrażonego”. Zob. L. Gandhi, Teoria postkolonialna: wprowadzenie krytyczne, tłum. J. Serwański, Poznań 2008, s. 16-179. zaowocowały w państwach europejskich formułowaniem programów ochrony i promocji stylów narodowych ${ }^{5}$. Idee te zyskiwały popularność zwłaszcza wśród narodów, które utraciły (bądź dopiero co zyskały) autonomię. Ich lokalne środowiska intelektualne i polityczne w sformułowaniu stylu narodowego upatrywały sprawnego narzędzia, mogącego mieć zastosowanie zarówno na potrzeby realizacji polityki wewnętrznej - integracji społecznej i etnicznej, jak i zewnętrznej - kreowania eksportowego wizerunku narodu na arenie międzynarodowej.

Ówczesny większościowy udział ludności chłopskiej w społeczeństwie polskim naturalnie kierował estetyczne poszukiwania ku ludowości ${ }^{6}$.Źródeł stylu narodowego

5 Zob. Nacjonalizm w sztuce i historii sztuki 1789-1950, red. D. Konstantynów, R. Pasieczny, P. Paszkiewicz, Warszawa 1998.

6 B. Brzostek, Czy folklor wszedł do śródmieścia? O motywach ludowych w PRL-u, w: Polska-kraj folkloru? [katalog wystawy, Zachęta Narodowa Galeria Sztuki], Warszawa 2016, s. 47. 


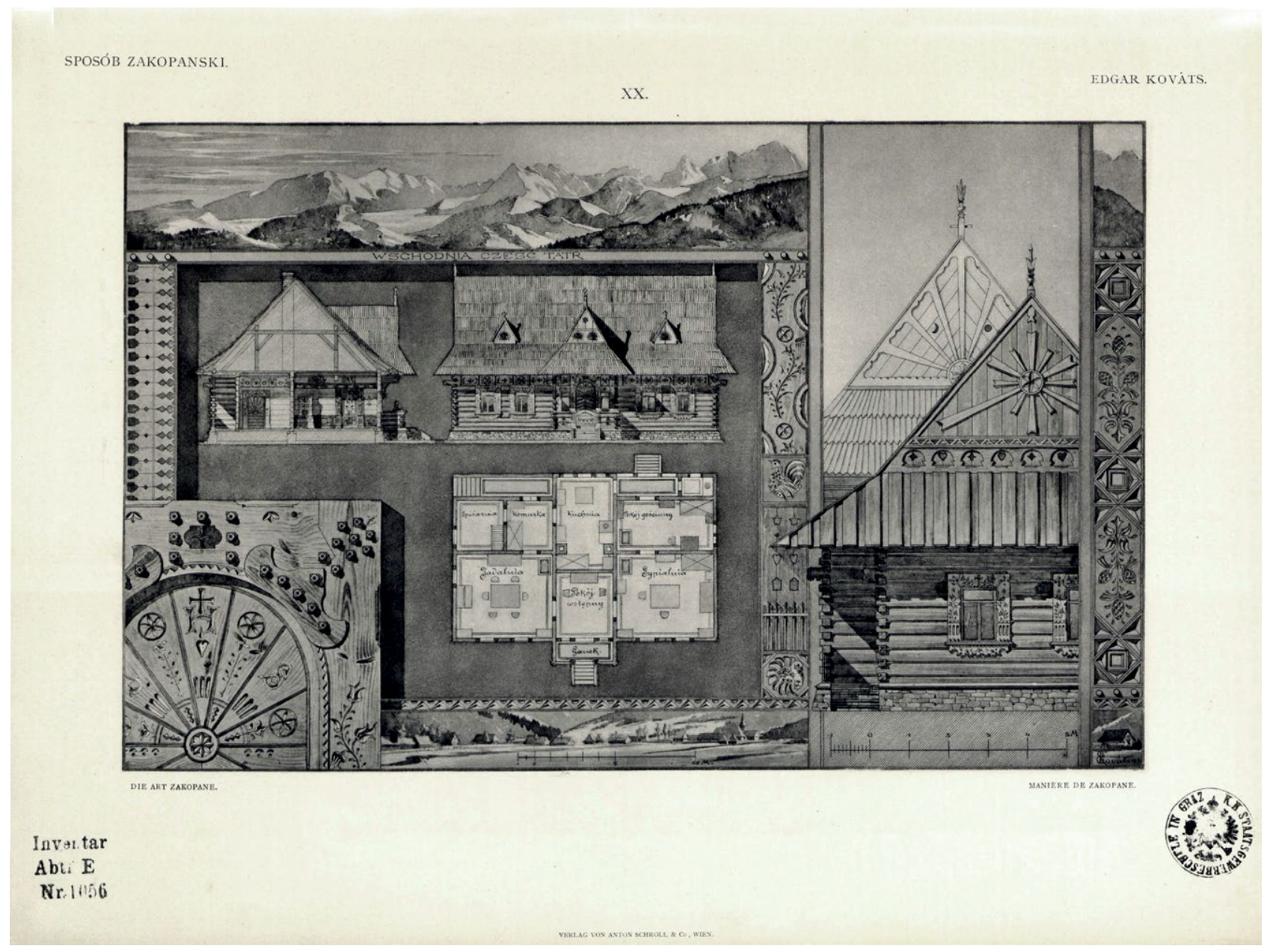

2. Edgar Kováts, Sposób zakopański,

Wiedeń-Lwów 1899, tabl. XX

upatrywano w góralszczyźnie, w której miały się rzekomo zachować elementy najdawniejszej kultury polskiej. U podłoża tych działań leżało przekonanie o autentyczności i braku skażenia cywilizacyjnego Podhala, o kultywowaniu przez miejscowych górali wartości moralnych i estetycznych, zapomnianych przez nowoczesną cywilizację.

Zorientowana na produkcję wyrobów z drewna Szkoła Snycerska, funkcjonująca od 1876 r. w Zakopanem, z uwagi na swoje położenie stała się kluczowym miejscem dla rozwoju koncepcji stylu narodowego bazującego na góralszczyźnie7.

7 Szkoła kilkakrotnie zmieniała nazwę: początkowo była Szkołą Snycerską, następnie C.K. Szkołą Fachową dla Przemysłu Drzewnego, od 1891 r. nosiła nazwę: C.K.
Powstanie placówki zostało zainicjowane przez Towarzystwo Tatrzańskie - społeczną instytucję założoną przez pochodzącego z Warszawy Tytusa Chałubińskiego w celu promowania i kultywowania przyrody i kultury góralskiej. Założenie zakopiańskiej szkoły zostało wpisane w szerszy pozytywistyczny program poprawy warunków życiowych miejscowej ludności i modernizacji Zakopanego ${ }^{8}$. Szlachetnie sformułowane cele pozostawały jednak

Szkoła Zawodowa Przemysłu Drzewnego. W 1918 r. przyjęła nazwę Państwowej Szkoły Przemysłu Drzewnego, pod którą przetrwała do drugiej wojny światowej. Historia placówki na podstawie: H. Kenarowa, dz. cyt., K. Chrudzimska-Uhera, dz. cyt.

8 D. Crowley, National Style and Nation-state. Design in Poland from the Vernacular Revival to the International Style, Manchester-New York 1992, s. 17. 
obcą ingerencją napływowej inteligencji w tradycję i kulturę miejscowej ludności ${ }^{9}$.

Działalność placówki promującej kulturę lokalną od samego początku zwracała uwagę władz austriackich, poszukujących sposobu na kolonizacyjną unifikację - włączenie tradycyjnej polskiej twórczości w obręb kultury Cesarstwa. Zaledwie dwa lata po otwarciu Szkołę przemianowano na państwową. Pierwsza próba zaborczej reformy lokalnego przemysłu pojawiła się w programie placówki już za kadencji Czecha Franciszka Neužila (1878-1895), a swoją finalną postać uzyskała podczas dyrektury artysty o polsko-węgierskich korzeniach - Edgara Kovátsa (1896-1901) ${ }^{10}$. Początki funkcjonowania placówki wyznaczały zatem propozycje formułowane przez przybywających do Zakopanego obcych, ukierunkowane na ten sam cel - modernizację regionu.

Programowa zmiana w czasach Neužila opierała się na prostej kompilacji ludowości podhalańskiej z tyrolską, tworzeniu eklektycznych kompozycji w oparciu o historyczne wzory zawarte w uniwersalnych, bogato ilustrowanych wzornikach i podręcznikach architektonicznych, popularnych w austriackim systemie edukacji ${ }^{11}$.

\footnotetext{
9 Przybywający na Podhale warszawianie uznawani byli pod koniec XIX w. za „odkrywców” Tatr. Chociaż byli przedstawicielami tego samego narodu co górale i w kulturze góralskiej poszukiwali własnej tożsamości, ich działania wiązały się z odmienną od lokalnej perspektywą, którą warunkowały klasa, rejon i motywacje. Na ten temat zob. M. Krupa, P. Mazik, K. Szpilka, Nieobecne miasto. Przewodnik po nieznanym Zakopanem, Wołowiec 2016, s. 60-102; Relacje Warszawa-Zakopane [katalog wystawy, Muzeum Rzeźby im. Xawerego Dunikowskiego - Oddział Muzeum Narodowego w Warszawie], Warszawa 2017.

10 T. Szybisty, «Sposób zakopański» i jego twórca Edgar Kováts (1849-1912), „Rocznik Podhalański”, t. 10, (za lata 2003-2006), 2007, s. 56

11 Ministerstwo Wychowania i Oświaty zaopatrywało szkołę w pomoce naukowe, co miało przełożenie na styl wykonywanych w niej prac. Szerzej na ten temat zob. T. Kędziora, Zakopiańska Szkoła Przemysłu Drzewnego w latach 1876-1918, „Studia Historyczne”,
}

W ramach programu nauczano więc stosowania ornamentów roślinnych niewystępujących na Podhalu czy też obcej sztuce góralskiej polichromii barwnej. Pomijając zachowanie pewnej dozy lokalnej ornamentyki (szyszki, symetryczne gałązki) i tematyki (przedstawienia górali w regionalnych strojach), stosowana w obrębie placówki metoda od stylu alpejskiego różniła się głównie wykonawcą, który był mieszkańcem Podhala.

Chęć bardziej świadomego ujarzmienia ludowości, potrzeba kodyfikacji i usystematyzowania obowiązującego w szkole programu, skłoniła Edgara Kovátsa do wydania w 1899 r. nowego, przeznaczonego dla regionu wzornika zatytułowanego Sposób zakopański ${ }^{12}$ (il. 2). „Sposób zakopański” stanowił propozycję nowego stylu regionalnego dla Podhala, będącego kompilacją lokalnych motywów stylistycznych (takich jak leluje, dziewięćsiły, parzenice czy słoneczka), historyzmu i stylu alpejskiego (motyw symetrycznych gałązek wyrastających z dzbana czy pryzmatyczne opracowania płatków kwiatów). Kováts w sposób swobodny posługiwał się elementami z różnych tradycji, łącząc je z własną redakcją motywów floralnych o trudnej do ustalenia taksonomii (we wzorniku odnajdziemy motyw kaczeńców, bławatów, kłosów, pnączy i drobnych kwiatów polnych). Chętnie sięgał także do wzorów geometrycznych (rozety, krzyżyki, karbowania, łezki, serduszka), polichromii i złoceń obcych tradycji góralskiej.

Rozbudowany ornament stanowił kostium dla historycznej struktury architektonicznej. Jak wskazuje historyczka sztuki Monika Stobiecka, ten propagowany niemal wyłącznie w obrębie zakopiańskiej placówki styl stanowił idealne ucieleśnienie programu artystycznego zaborcy, zakładającego

t. 36, 1993, z. 4 (143), s. 477-488.

12 Szczegółowe omówienie tej publikacji czytelnik znajdzie w artykule: T. Szybisty, dz. cyt., s. 74-76. 
projektowanie „wyobrażonego” regionalizmu na pograniczach cesarst $\mathrm{wa}^{13}$.

Na przełomie XIX i XX w. działalność zakopiańskiej placówki spotkała się z wyraźnym sprzeciwem zafascynowanego kulturą Podhala malarza i krytyka artystycznego Stanisława Witkiewicza'4. Propagowany przez niego od lat 9o. styl zakopiański stanowił architektoniczno-artystyczną kontrpropozycję dla promowanej przez dyrekcję zakopiańskiej szkoły formuły, korzystającej z wpływów alpejskich i stylów historycznych (il. 3). Witkiewicz sformułował swą koncepcję w oparciu o doświadczenia tradycyjnego podhalańskiego budownictwa, charakteryzującego się racjonalizmem

13 M. Stobiecka, dz. cyt.

14 A. Kluczewska-Wójcik, What art Poland needs: in search of the Polish national style at the beginning of the 20th century, w: History of Art History in Central, Eastern, and South-East Europe, red. J. Malinowski, Toruń, 2012, s. 149-154. technologicznym i funkcjonalizmem stosowanych rozwiązań. Wraz z mnożącymi się narracjami opisującymi styl zakopiański jako styl „prapolski” doszło do rozbudowy koncepcji: z regionalnej propozycji styl zakopiański stał się podstawą dla formułowania stylu narodowego. Nacjonalizację tę odczytać można również jako efekt rywalizacji z zaborczym „sposobem zakopiańskim” z perspektywy postkolonialnej była to forma oporu wobec "miękkiej polityki” narzucanej przez zaborcę w postaci promocji „sposobu zakopańskiego" ${ }^{15}$. Jak argumentuje historyk sztuki Andrzej Szczerski, propozycja Witkiewicza była jednak nie tylko próbą opracowania nowej, konkurencyjnej stylistyki i narodowej formy, ale także „złożonym projektem reformatorskim i politycznym"16. Wdrożenie stylu narodowego

15 M. Stobiecka, dz. cyt.

16 A. Szczerski, dz. cyt, s. 20.

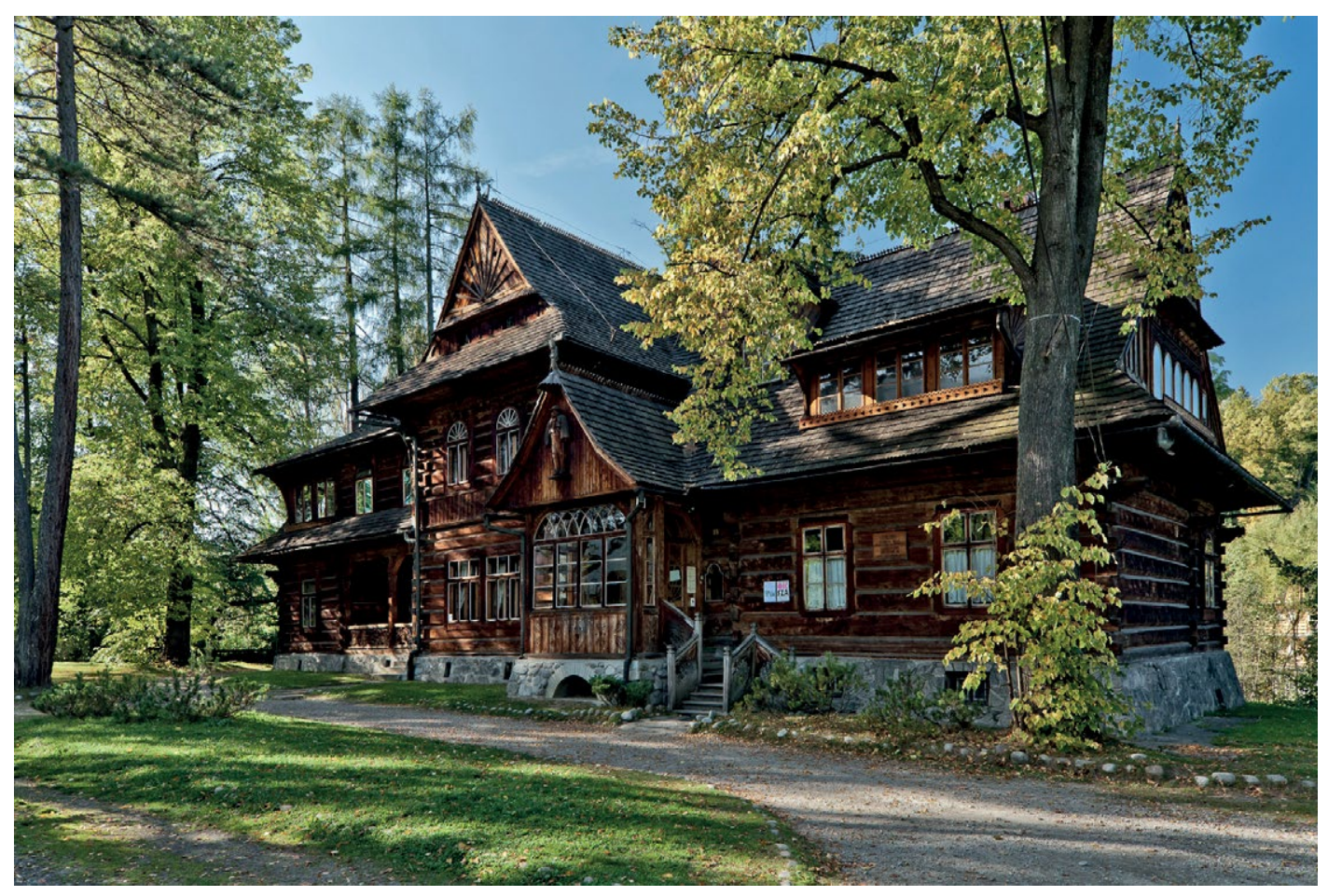

3. Stanisław Witkiewicz, Willa Koliba,

Zakopane, 1891-1892. Fot. Piotrekwas 
artysta utożsamiał „z procesem demokratyzacji, a pojęcie narodu miało wydźwięk egalitarny, pozwalający każdemu bez względu na pochodzenie społeczne $\mathrm{z}$ nim się utożsamiać"17. Najbardziej wzniosłe w myśli Witkiewicza było jednak założenie, że hasła narodowej odrębności powinny służyć podkreśleniu nie tyle wagi polskiej tradycji, co całej wspólnoty cywilizacyjnej dawnych ziem Rzeczypospolitej. Co więcej, Witkiewiczowski styl miał wspierać śmiały i skierowany w przyszłość projekt nowej konstrukcji Europy.

Mimo bardzo ostrego sporu, szeroko komentowanego na łamach prasy przez środowiska warszawskie (zwolenników stylu zakopiańskiego) i krakowskie (orędowników „sposobu”), podejścia Kovátsa i Witkiewicza do ludowości wykazywały zaskakująco dużo podobieństw, pomijanych zazwyczaj w kontekście skrajnie spolaryzowanych stanowisk. Podczas gdy Kováts krytykowany był za systematyzowanie podhalańskich wzorów i rozwiązań architektonicznych na równi ze szwajcarskimi i tyrolskimi, Witkiewicz dokonywał analogicznego zabiegu w praktyce - kondensując motywy zakopiańskie i wyrywając je z kontekstu, co niejednokrotnie odbierało rozwiązaniom architektonicznym właściwe im funkcje. Zamierzeniem Kovátsa było stosowanie wypracowanych w ten sposób wzorców ludowych dla przekształcenia letniska w kurort spójny z podobnymi tego typu lokalizacjami na terenie cesarstwa. W tle idei Witkiewicza zaś styl zakopiański promował region i zmierzał do uczynienia z Zakopanego kurortu dla inteligencji pochodzącej z terenów przedrozbiorowej Rzeczypospolitej. Próba zawłaszczenia ludowości, do jakiej dochodziło w ramach prowadzonej przez Kovátsa placówki, spotykała się zatem z reakcją środowiska polskich elit, równie instrumentalnie traktujących tradycję lokalną. Silna polaryzacja tego sporu i towarzysząca mu burzliwa debata wpływała na dynamikę procesu, przyczyniając się do mitologizacji góralszczyzny i pseudonaukowego dowodzenia „prapolskości” - wszystko na potrzeby mody, lansowania własnej koncepcji.

Warto podkreślić, że z pozoru przeciwstawne koncepcje - stylu i „sposobu zakopiańskiego" zostały ufundowane na podobnych podstawach. Bazowały na regionalnej wytwórczości, próbie sprowadzenia dziedzictwa kulturowego do zaledwie kilku charakterystycznych jego elementów, zawłaszczenia kultury przez obcych dla obcych.

Po ustąpieniu Kovátsa w 1901 r. dyrektorem placówki został Stanisław Barabasz, pierwszy Polak na tym stanowisku, za kadencji którego szkoła zaczęła funkcjonować w niepodległym państwie. Wykształcony w krakowskim Instytucie Technicznym, na Politechnice Wiedeńskiej oraz w Szkole Przemysłu Artystycznego przy Austriackim Muzeum Sztuki, Barabasz odszedł od dotychczas obowiązującej w nauczaniu metody kopiowania eklektycznych historycznych wzorów na rzecz propagowania motywów zaczerpniętych z lokalnej sztuki ludowej. Decyzja ta mogła zostać częściowo podyktowana zainteresowaniami i doświadczeniami zebranymi podczas dotychczasowej pracy pedagogicznej w założonej przez niego w 1883 r. Szkole Rysunku i Modelowania, działającej przy Muzeum Techniczno-Przemysłowym w Krakowie ${ }^{18}$.

\footnotetext{
18 Muzeum Techniczno-Przemysłowe w Krakowie powstało w 1868 r. z inicjatywy Adriana Baranieckiego. Zbiory obejmowały obiekty rzemiosła artystycznego i użytkowego polskiego oraz zagranicznego (w tym wyroby metalowe, jubilerskie, ceramikę, szkło, tkaniny), a także wytwory polskiej i obcej sztuki ludowej. Instytucja prowadziła warsztaty propagujące rodzime tkactwo i ceramikę. Na ten temat zob. P. Hapanowicz, Działalność Muzeum Techniczno-Przemysłowego w Krakowie i jego likwidacja w latach 1949-1950, „Zarzadzanie w Kulturze”, t. 8, 2007, s. 43-62.
} 


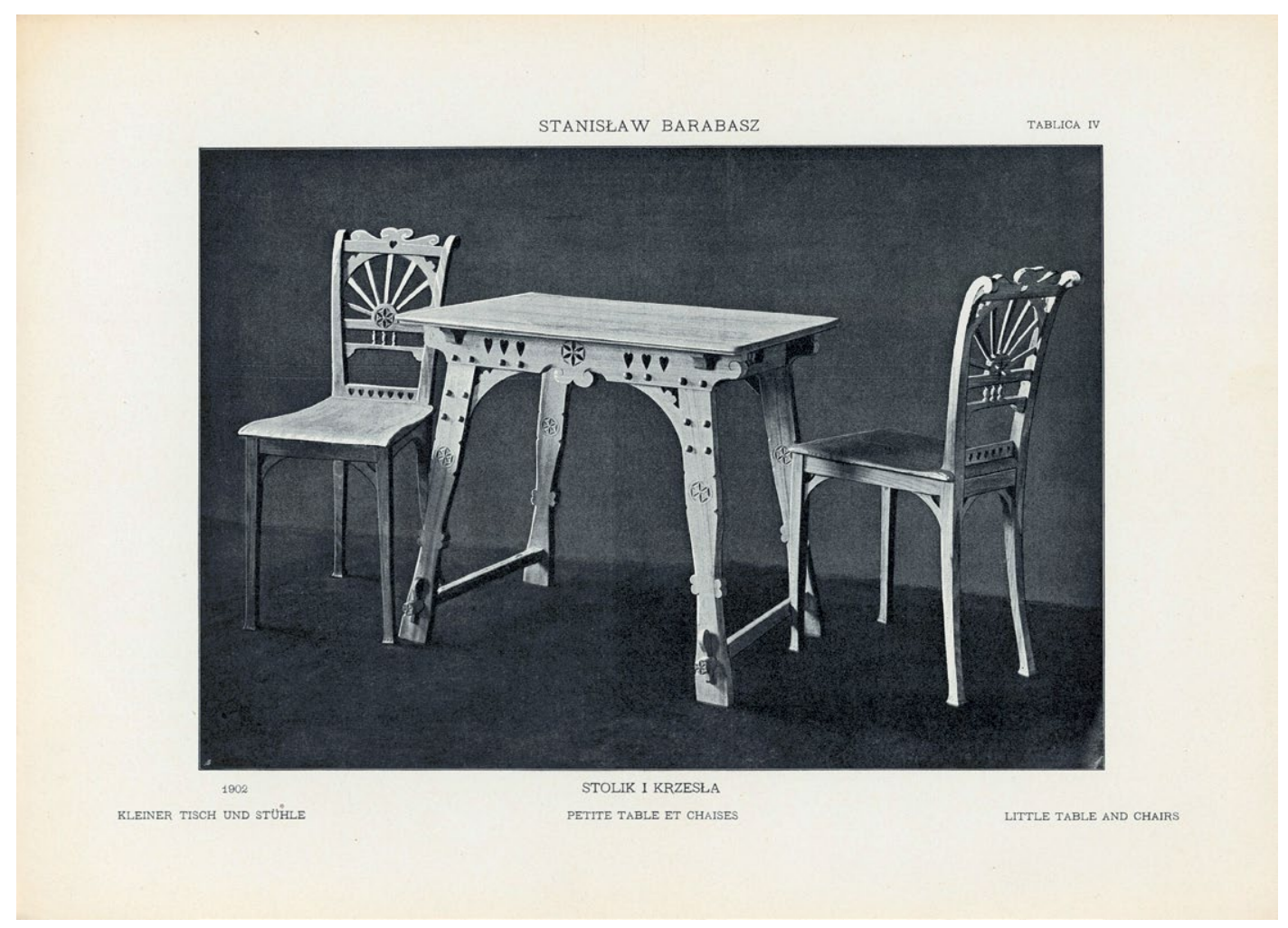

4. Stanisław Barabasz, stolik i krzesła, 1902 r. Fot. wg: S. Witkiewicz, Styl zakopiański, z. 1: Pokój jadalny, Lwów 1904, tabl. IV.

Za kadencji Barabasza doszło do kompromisu z Witkiewiczem, którego owocem była wspólnie opracowana publikacja - Styl

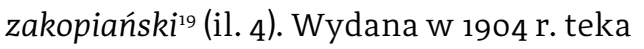
obok wypowiedzi Witkiewicza zawierała wzorcowe projekty mebli do pokoju jadalnego autorstwa kilku artystów, w tym Barabasza. Zaproponowany przez dyrektora zakopiańskiej szkoły projekt nie spotkał się jednak z pełnym uznaniem Witkiewicza z uwagi na brak gzymsu i zbyt swobodne operowanie formami stanowiącymi dotychczasowy kanon stylu zakopiańskiego ${ }^{20}$. Krytyka ta nie była bezpodstawna, gdyż wizja góralskiej ludowości Barabasza faktycznie wykraczała poza Witkiewiczowskie rozumienie „stylu”. W murach zarządzanej przez niego placówki nie nauczano stylu zakopiańskiego sensu stricto - podhalański kanon poszerzony został o wzory z terenu

19 S. Witkiewicz, Styl zakopiański, z. 1:Pokój jadalny, Lwów 1904, tabl. IV.

20 K. Chrudzimska-Uhera, dz. cyt., s. 49.
Orawy i Spisza ${ }^{21}$. Dokonywano też stylizacji podług popularnych w Krakowie secesyjnych wzorów, co stanowiło przedłużenie zaborczej polityki - zmianę formalną zgodną z obowiązującymi w Wiedniu tendencjami ${ }^{22}$.

Dopiero Karol Stryjeński, dyrektor w latach 1922-1927, zerwał w stosunku do ludowości ze schematami swoich poprzedników. Zanim Stryjeński objął posadę w Szkole Przemysłu Drzewnego w Zakopanem, studiował w Zurychu (na Politechnice) i w Paryżu (w École Nationale Supérieure des Beaux-Arts). Ważnym

21 Tamże, s. 49. Wieloletnie zainteresowanie Barabasza sztuką ludową i zabytkami sztuki na Podhalu, Spiszu i Orawie zaowocowało czterotomową publikacją Sztuka ludowa na Podhalu, wydaną w latach 1928-1932. Każda z części zawiera partię opisową omawiającą cechy charakterystyczne regionu oraz tablice prezentujące wybrane eksponaty. S. Barabasz, Sztuka ludowa na Podhalu, cz. 1-2: Spisz i Orawa, Lwów-Warszawa 1928; cz. 3: Witów, Lwów-Warszawa 1930; cz. 4: Kościół w Dębnie, Lwów-Warszawa 1932.

22 K. Chrudzimska-Uhera, Secesja w Zakopanem?, „Pamiętnik Sztuk Pięknych”, 2015, nr 10, s. 341-346. 
składnikiem jego edukacji były także wizyty w siedzibie Muzeum Techniki i Przemysłu w Krakowie, zaprojektowanej przez jego ojca, niegdysiejszego dyrektora placówki (1907-1910), znanego architekta i czynnego propagatora stylu zakopiańskiego - Tadeusza Stryjeńskiego ${ }^{23}$. Istotne tło jego kariery w Zakopanem stanowiła także współpraca z firmą architektoniczno-budowlaną prowadzoną przez ojca. To właśnie z tych miejsc płynęły impulsy dla jego późniejszej, reformatorskiej koncepcji pedagogicznej.

Nowa postawa wobec „prymitywu”, praktykowana w murach zakopiańskiej szkoły, zakładała już nie powielanie utrwalonych wzorów ludowych, lecz stymulowanie nieskażonej jeszcze narzuconymi schematami postępowania wyobraźni artystycznej młodych adeptów placówki. Ta z pozoru szlachetna inicjatywa, szansa na tchnięcie nowego życia w system nauczania ludowości, wciąż była jednak wpisana w stojące u podstaw Szkoły wytwórstwo na potrzeby przemysłu ${ }^{24}$.

Stosowana za kadencji Stryjeńskiego metoda nauczania pozostawiała wychowankom swobodę w zakresie wyboru tematu i sposobu jego realizacji - zakładała tworzenie z wyobraźni bezpośrednio w materiale. Nauczyciel otrzymał nową rolę miał nadzorować i czuwać nad samorodnym talentem artysty „ludowego”. Innym ważnym aspektem wspomnianej metody było zainteresowanie praktykowaniem tradycyjnych umiejętności technicznych i technologicznych. Tak skonstruowany system edukacji wiele zawdzięczał krakowskim koncepcjom nauczania

23 Chodzi o willę Koliba, wybudowaną w latach 1892-1894 dla Zygmunta Gnatowskiego według projektu Stanisława Witkiewicza. J. Skrzypczak, Styl zakopiański w twórczości Tadeusza Stryjeńskiego, „Rocznik Podhalański”, t. 10, 2007, s. 105-126.

24 K. Stryjeński, Szkoła Przemysłu Drzewnego, „Giewont", 1924, nr 1, s. 27. propagowanym wpierw przez Antoniego Buszka (1883-1954) ${ }^{25}$, a następnie przez środowisko stowarzyszenia Warsztatów Krakowskich, którego Karol Stryjeński był aktywnym członkiem ${ }^{26}$. Przywołana metoda zrodziła się w środowisku krakowskim na kanwie dyskusji o stylu narodowym i znaczeniu sztuki ludowej w jego kształtowaniu oraz o kierunku rozwoju rzemiosła artystycznego wobec zmian zachodzących w sposobach wytwarzania przedmiotów użytkowych. Reorganizacja szkolnictwa artystycznego w II Rzeczypospolitej, poszukiwania nowych metod kształcenia i języka wypowiedzi artystycznej są adekwatnym punktem odniesienia także dla przemian, do jakich dochodziło w szkole pod Tatrami ${ }^{27}$.

Stryjeński był zainteresowany sztuką ludową z uwagi na tkwiącą w niej mądrość opracowania materiału, autentyczność, spontaniczność, prostotę kompozycji i oszczędność środków artystycznych. Podkreślenie w powstających w obrębie placówki pracach tak ujmowanych walorów „prymitywu” łączyło tę twórczość z popularnymi wówczas tendencjami modernistycznymi - powrót do ludowości wiązał się z zasadniczą dla nowoczesności ideą regeneracji sztuki. W ramach wdrażania programu dochodziło do stopniowego odstępowania od ścisłej interpretacji ludowego wzorca na rzecz jego przetworzenia podług

25 Więcej na temat działalności Antoniego Buszka: K. Liwak, Eksperymenty Antoniego Buszka z twórcami ludowymi, w: Polskie szkolnictwo artystyczne. Dziejeteoria-praktyka, red. M. Poprzęcka, Warszawa 2005, s. 193-199; K. Chrudzimska-Uhera, Stylizacje..., dz. cyt., s. 250-251.

26 Warsztaty Krakowskie działały od 1913 r. przy krakowskim Muzeum Techniczno-Przemysłowym, mając na celu odnowę rodzimego rzemiosła artystycznego. Zob. Warsztaty Krakowskie 1913-1926, red. M. Dziedzic, Kraków 2009.

27 Polskie szkolnictwo..., dz. cyt., Szkolnictwo artystyczne, w: Polskie życie artystyczne w latach 1915-1939, red. A. Wojciechowski, Wrocław-Warszawa-KrakówGdańsk 1974, s. 514-534. 


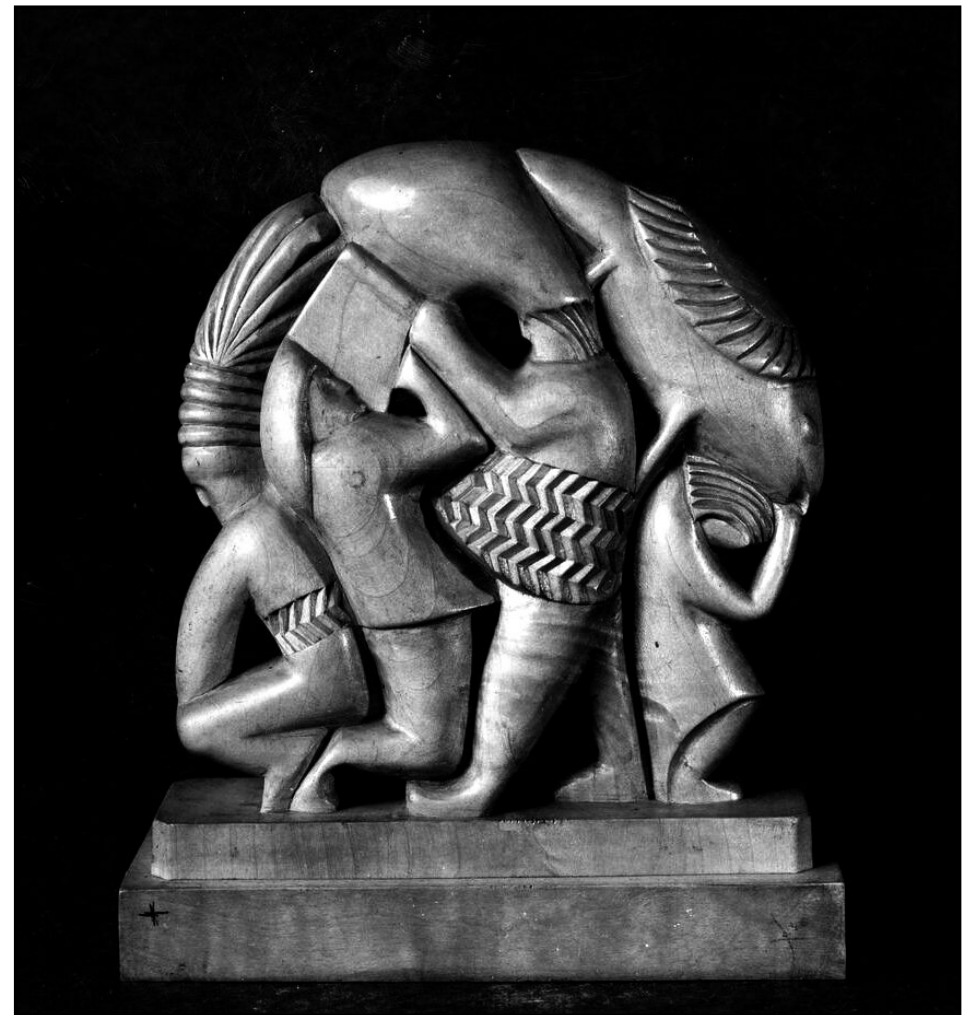

5. Autor nierozpoznany, rzeźba wykonana w Państwowej Szkole Przemysłu Drzewnego w Zakopanem na Międzynarodową Wystawę Sztuk Dekoracyjnych i Nowoczesnego Przemysłu w Paryżu, 1925 r. Fot. MNW nowych schematów estetycznych, konsekwentnego poszerzania o elementy dekoracyjności i stylizacji ${ }^{28}$.

W opracowaniach zagadnienia międzywojennego powrotu do ludowości wśród twórców szkoły zakopiańskiej dominuje przekonanie o skupieniu artystów wyłącznie na sztuce i pejzażu Podhala ${ }^{29}$. Taka perspektywa jest jednak budowana bez pytania o charakter ludowości, leżącej u podstaw zjawiska. Podobieństwa formalne realizacji powstałych podczas dyrektury Stryjeńskiego sugerują, że wbrew

28 Dzięki takim zabiegom egzotyczna twórczość rdzennych mieszkańców Stanów Zjednoczonych stawała się bliska. K. Chrudzimska-Uhera, Stylizacje..., dz. cyt, s. 262.

29 Zob. m.in. P. Policht, Jak wymyślano podhalańska ludowość, 2019, culture.pl: https://culture.pl/pl/ artykul/jak-wymyslano-podhalanska-ludowosc [dostęp 17 I 2020]. Cenny wyjątek w tym zakresie stanowią badania Katarzyny Chrudzimskiej-Uhery, zob. K. Chrudzimska-Uhera, Stylizacje..., dz. cyt. programowemu odrzuceniu wzorników uczniom udostępniano jednak pewne materiały pomocnicze. Źródeł inspiracji poszukiwano przypuszczalnie nie, jak mogłoby się wydawać, w podhalańskiej rzeźbie (z uwagi na jej niewielki udział w ikonosferze regionu), ale również w regionalnej sztuce graficznej i malarstwie na szkle ${ }^{30}$. Ważne źródło odniesienia dla twórczości uczniów stanowiły chrześcijańskie ludowe przedstawienia sakralne oraz ikonografia dawnych bóstw słowiańskich ${ }^{31}$. Wśród realizacji z tego okresu odnajdujemy tematy wskazujące także na zainteresowania odległą ludowością zachodnią, na przykład Indianami ${ }^{32}$. Dowodem mieszania elementów zaczerpniętych z różnych kultur ludowych w twórczości środowiska Szkoły były inspirowane „sztuką prymitywną” wyroby prezentowane na Międzynarodowej Wystawie Sztuk Dekoracyjnych i Nowoczesnego Przemysłu w 1925 r., m.in. rzeźba Zbójnik ze smokiem.

W na powrót niepodległej Polsce przez ponad dekadę źródeł stylu narodowego poszukiwano w ludowości, dlatego też na wspomnianej wystawie w Paryżu w 1925 r. w dziale polskim prezentowano głównie realizacje inspirowane folklorem, w tym także prace zakopiańskiej Szkoły Przemysłu Drzewnego (il. 5). Prace Karola Stryjeńskiego i jego wychowanków zostały uhonorowane nagrodami - ówczesny sukces wyrobów na wiele lat zaważył na recepcji

\footnotetext{
30 Tamże, s. 261.
}

31 Temat zainteresowania pogańskimi teogoniami w środowisku zakopiańskim wciąż wymaga opracowania. Badania na ten temat w twórczości żony Karola Stryjeńskiego - Zofii zainicjowała Agnieszka Żuber. A. Żuber, Ikonografia cyklu grafik Bożki słowiańskie Zofii Stryjeńskiej, w: Polskie art déco. Materiały siódmej sesji naukowej „Polskie art déco. Malarstwo i grafika” pod przew. prof. A. Sieradzkiej, prof. A.K. Olszewskiego i dr A. Kostrzyńskiej-Miłosz w Muzeum Mazowieckim w Płocku 23-24 października 2017 roku, red. Z. Chlewiński, Płock 2017, s. 92-121.

32 K. Chrudzimska-Uhera, Stylizacje..., dz. cyt, s. 258. 
projektów powstających w obrębie placów$\mathrm{ki}^{33}$. Zaproponowana przez zakopiańską uczelnię redakcja stylu narodowego została doceniona także na arenie krajowej. Produkty Szkoły stały się przedmiotem pożądania, ucieleśniającym aspiracje polskiej inteligencji. Realizacje kojarzono z patriotycznym i nowoczesnym wyposażeniem mieszkania - stanowiły bowiem propozycję swojskiej dekoracji, alternatywę dla nurtu historycznych i eklektycznych wyrobów ubiegłych dekad, naznaczonych wizją obcości.

Wypracowana podczas kadencji Stryjeńskiego wizja ludowości już na początku lat 30. częściowo straciła na znaczeniu. Stało się tak za sprawą nie tylko zmiennej mody i koniunktury (kryzysu ekonomicznego 1929 r.), ale było także rezultatem zmiany koncepcji strategicznych i programowych placówki. Wskutek dużego zainteresowania rzeźbami Szkoły po sukcesie odniesionym w Paryżu w 1925 r., pod koniec lat 20., za kadencji Adama Dobrodzickiego (1929-1936) ${ }^{34}$, znacznie zwiększono liczbę produkowanych wyrobów, które w zamierzeniu miały trafiać przede wszystkim na rynek zagraniczny m.in. do Stanów Zjednoczonych, Kanady i Australii ${ }^{35}$. Wykorzystując ludowe motywy, podejmowano próby konstruowania polskiej tożsamości na arenie międzynarodowej.

Prezentowane na światowych wystawach figurki miały znaczenie polityczne - budowały obraz Polski jako kraju zarazem otwartego na nowe tendencje i zakorzenionego w tradycji. Eksport służył też

33 Wystawa paryska 1925. Materiały z sesji naukowej Instytutu Sztuki PAN, red. J. Sosnowska, Warszawa 2007; K. Nowakowska-Sito, W poszukiwaniu niepodległości w sztuce. Pawilon polski na wystawie paryskiej 1925, „Idea. Studia nad strukturą i rozwojem badań filozoficznych", t. 30, 2018, nr 1, s. 185-196.

$34 \mathrm{Z}$ uwagi na krótki okres pełnienia funkcji dyrektora nie omawiam kadencji Wojciecha Brzegi (1927-1929).

35 K. Malinowski, Szkoła rzeźby w Zakopanem, „Arkady”, 1937, nr 10, s. 544 budowaniu więzi z polską diasporą. Dla przyspieszenia produkcji nie tylko powrócono do modelu powielania kompozycji projektowanych przez nauczycieli, ale także dokonano zakupu maszyny kopiującej, mającej umożliwić sprawną replikację szkolnych wyrobów $^{36}$.Z uwagi na docelowy eksport realizacje poddano obcej, abstrakcyjno-geometryzującej modernizacji (il. 6). Zmiany te można interpretować poprzez zaproponowaną przez Piotra Kordubę kategorię ludowości na handel ${ }^{37}$, służącą do opisu masowej produkcji wyrobów rękodzielniczych okresu międzywojnia, w obrębie których ludowość nie była przedmiotem etnograficznej refleksji, lecz próbą stworzenia jej ulepszonej, rynkowo atrakcyjnej wersji. Całkowicie zrezygnowano z poszukiwań formalnych w obrębie „prymitywu”, odrzucając nawet typową dla rzeźby ludowej hieratyczność na rzecz skomplikowanych, dynamicznych układów kompozycyjnych. Dokonano także wykroczenia poza tradycyjne przedstawienia związane z ludowością, poszerzając spektrum tematów o wizerunki zwierząt i dzieci. Tworzone za kadencji Dobrodzickiego figurki, utrzymane w duchu estetyki art déco, przeznaczone były bowiem na potrzeby zbytu - wystaw, miejskich klientów $\mathrm{i}$ instytucji. Wyłania się z nich wizerunek ludu roztańczonego i umuzykalnionego, uproszczony, odwołujący się do sentymentalnej wizji sielskiego życia, skierowany do możliwie szerokiego grona odbiorców (il. 7).

36 Dobrodzicki zalecił, by każda rzeźba wykonywana była wpierw w jednym, autorskim egzemplarzu, a następnie przy pomocy maszyny - przyrządu do punktowania (zwanego też punktownicą bądź pantografem rzeźbiarskim), tworzono cztery jej kopie. K. Chrudzimska-Uhera, Stylizacje..., dz. cyt., s. 302.

37 P. Korduba, Jak wymyślono „ludowość na handel” - czyli o popieraniu przemysłu i sztuki ludowej w międzywojennej Polsce, „Artium Quaestiones”, 2012, nr 23, s. 59; tenże, Ludowość na sprzedaż. Towarzystwo Popierania Przemysłu Ludowego, Cepelia, Instytut Wzornictwa Przemysłowego, Warszawa 2013, s. 13. 


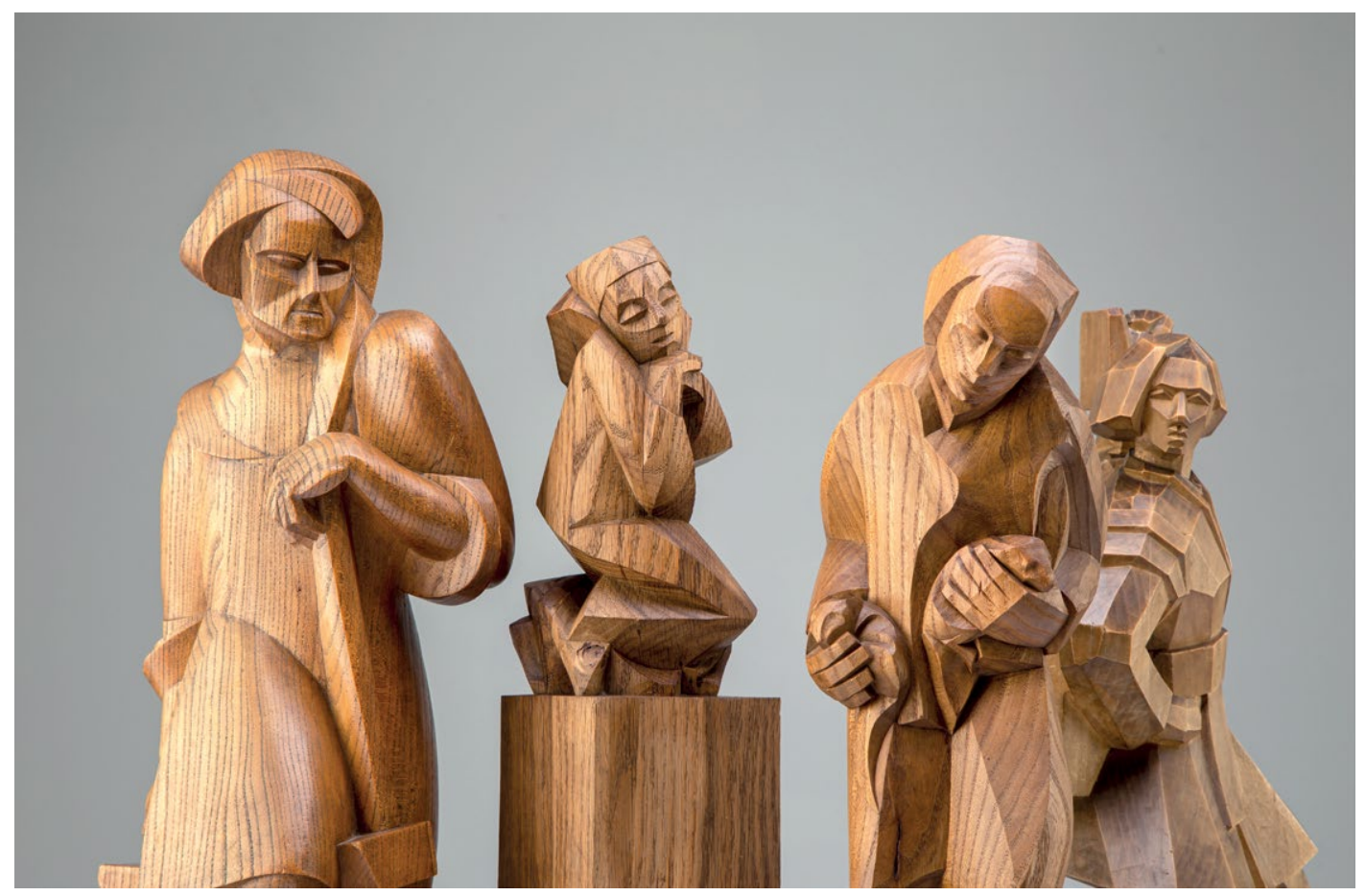

6. Od lewej: 1. Władysław Raś, Kowal, snycerka/drewno, 1933 r., kolekcja prywatna; 2. autor nierozpoznany, Modlący się, drewno, lata 30. XX w., kolekcja prywatna; 3. autor nierozpoznany, Nagroda za Bieg Zjazdowy o puchar P.K.L. (1946), drewno, lata 30. XX w., kolekcja prywatna; 4. autor nierozpoznany, Krakowiak, drewno, 1934 r., kolekcja prywatna. Fot. Desa Unicum, P. Bobrowski

Narracja łącząca tradycję z nowoczesnością, międzynarodowe tendencje z patriotyzmem lokalnym, naznaczona była głębokimi sprzecznościami. Realizacje powstające w ramach zakopiańskiej szkoły miały być wyrazem spontanicznych działań twórców ludowych, zarazem jednak kontrolowano je instytucjonalnie, zgodnie z panującą polityką rządową. Masowość wyrobów miała stanowić gwarancję napływu zagranicznego kapitału, którego instytucja, gospodarka regionu i niedawno utworzonego państwa bardzo potrzebowały. Pod dyrekcją Dobrodzickiego, kierując się interesem rynkowym dostosowywaniem do potrzeb konsumentów, wykonano krok ku zatraceniu ludowej tożsamości rzemiosła z regionu. Do nieodwracalnych przemian w ikonosferze doszło już pod koniec XIX w., gdy turystyczny rozwój Podhala i instytucjonalizacja rzemiosła na potrzeby zewnętrznych podmiotów znacząco wpłynęły na przemiany w obrębie lokalnej tradycji. Oryginalny folklor, dopasowywany do obowiązujących, obcych narracji stopniowo zanikał. Odpowiedzialni za zmiany wciąż łudzili się jednak co do jego wiecznotrwałości i wartości niepodlegających destrukcyjnemu działaniu czasu.

Jak słusznie wskazuje Piotr Korduba, już w okresie międzywojnia „nieśmiało” dostrzegano niebezpieczeństwa związane z propagowaniem ludowości w obrębie współczesnej sztuki dekoracyjnej ${ }^{38}$. Wspomniane głosy pojawiały się w środowiskach zwolenników tej idei, dostrzegających ryzyko niezrozumienia stojącej za nią koncepcji ${ }^{39}$ czy uzyskania wrażenia zastoju rozwoju kultury polskiej, jak i wśród jej przeciwników, zwracających uwagę między innymi na wyalienowanie projektu z ogólnoeuropejskich tendencji czy nieświadomość i oderwanie artystów od potrzeb życia współczesnego ${ }^{40}$.

38 Tenże, Ludowość..., dz. cyt., s. 22.

39 J. Warchałowski, O sztuce stosowanej, Kraków 1904, s. 4. 40 Czy sztuka dekoracyjna?, „Blok”, 1925, nr 10, s. 1. 
Analizując historię placówki, należy zwrócić uwagę na ważną składową sztuki ludowej, która pozostawała przez lata trwałym nośnikiem tradycji, wymykającym się programowym zawłaszczeniom. Niezależnie od zmian strategii placówki formułowanych przez kolejnych dyrektorów, niezmiennie zachowywano związki z jej pierwotnym snycerskim profilem - leżącym u podstaw nauczania drewnem i technikami jego obróbki ${ }^{41}$. Jak wskazuje historyczka sztuki Aleksandra Giełdoń-Paszek, rozbudzone za sprawą działalności Witkiewicza i Kovátsa pod koniec XIX w. zainteresowanie góralszczyzną wpłynęło na nobilitację tego materiału ${ }^{42}$. Na przestrzeni lat drewno - traktowane utylitarnie zwłaszcza przez ludność góralską - ewoluowało do rangi szlachetnego tworzywa ${ }^{43}$.

Choć debatę nad jego znaczeniem w sztuce rodzimej rozpoczęły rozważania dotyczące konieczności wykorzystania drewna iglastego w budownictwie góralskim, w kolejnych dekadach chętnie sięgano do wszystkich gatunków drewna, uznając je za materiał tradycyjny, „prapolski”. W doborze gatunków stosowanych w Szkole Przemysłu Drzewnego w Zakopanem dużą rolę odegrały względy praktyczne: dostępność surowca, cena i charakter tworzywa (kolor i usłojenie wpływały dodatkowo na wartości estetyczne realizacji). Najchętniej wybierano gatunki drewna o zwartej

41 W obrębie placówki tworzono także realizacje w innych materiałach, m.in. gipsie czy ceramice.

42 A. Giełdoń-Paszek, Drewno a sprawa polska: wykorzystanie drewna w poszukiwaniu polskiego stylu narodowego, „Studia Artystyczne”, 2015, nr 3, s. 134.

43 By w latach 20. zostać wykorzystane jako element legitymizowania nowego stylu narodowego, o czym świadczy m.in. sformułowany na marginesie rozważań o zabawkarstwie polskim postulat eksploatacji drewna przez Polskę, żeby podbić inne kraje „egzotyzmem swoim” i wywołać modę na polszczyznę, wystosowany przez Bronisława Mańkowskiego w 1920 r. B. Mańkowski, Zabawkarstwo w Polsce. Możliwość jego rozwoju na podstawie przykładów państw obcych, Warszawa 1920, s. 12.

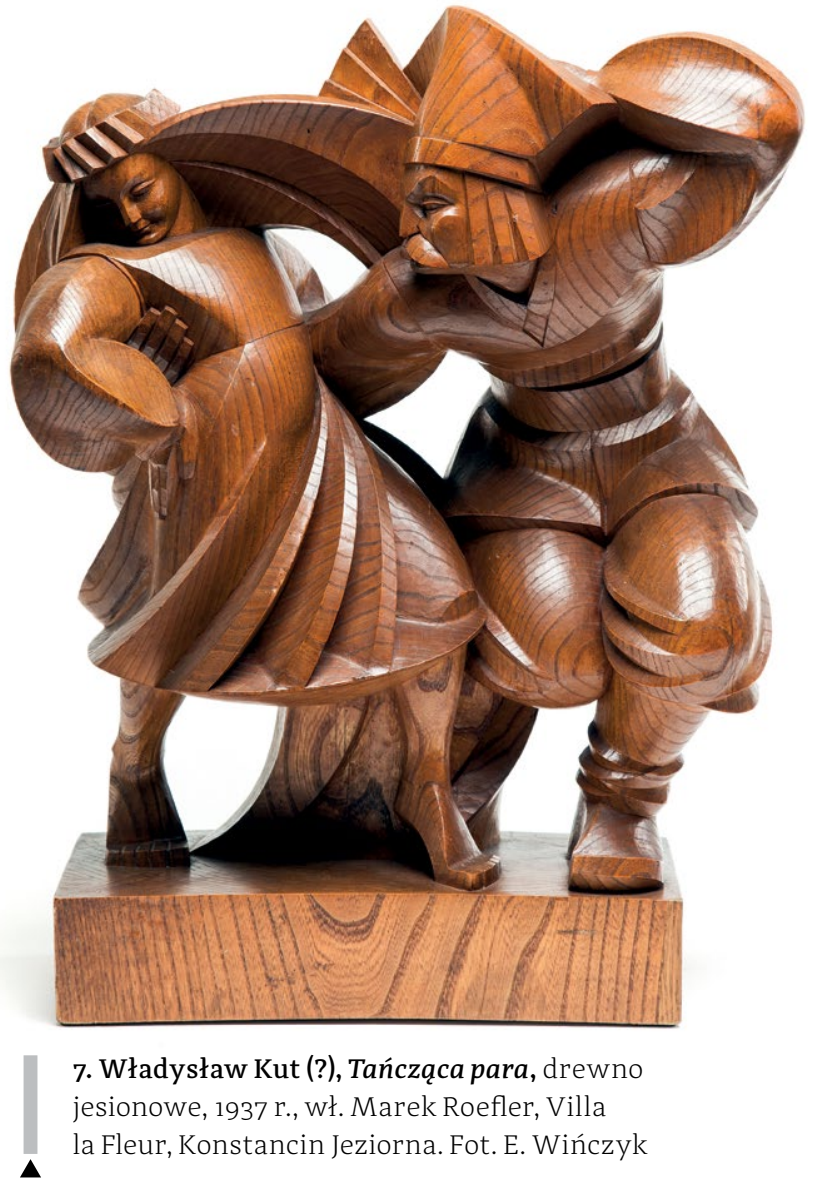

strukturze, twarde i odporne na czynniki atmosferyczne, które powszechnie występowały na terenie Podhala: jesion, wiąz górski, dąb, jawor, drzewa owocowe. Rzadziej decydowano się na wykorzystanie drzew iglastych, obfitujących w żywicę (cechujących się mniej urozmaiconym rysunkiem). Wybór lokalnych gatunków drewna odpowiadał ważnemu z perspektywy ekonomicznej państwowemu programowi wykorzystania surowców miejscowych ${ }^{44}$. Co istotne, stanowił także pomost łączący współczesne rzemiosło z przeszłością z czasami polegania wyłącznie na surowcach lokalnych, w których drewno otoczone było szeregiem ludowych wierzeń ${ }^{45}$.

O stosowaniu drewna w obrębie Szkoły Zawodowej Przemysłu Drzewnego w Zakopanem decydowały też względy

44 P. Korduba, Jak wymyślono „ludowość..., dz. cyt., s. 59.

45 Rzeźba w drewnie w twórczości polskich artystów 1918-2018 [katalog wystawy, Miejska Galeria Sztuki im. Władysława hr. Zamoyskiego], Zakopane 2018, s. 5. 
pragmatyczne: przekazywane umiejętności obróbki surowca. Do opracowywania materiału używano narzędzi szeroko wykorzystywanych w miejscowej snycerce, budownictwie i ciesielstwie: pił, siekier, dłut snycerskich (umożliwiających nacinanie brzegów - skośników, wykonywanie zagłębień - żłobników, czy opracowywanie wypukłych powierzchni - dłut typu łyżka), a także pilników (tarników) ${ }^{46}$. Dostępne narzędzia i fizyczne właściwości drewna determinowały formy realizacji, narzucały twórcom środki ekspresji, przynosząc za każdym razem inne rezultaty. O zróżnicowaniu tym decydowały w dużej mierze indywidualne doświadczenia i umiejętności, technika, a także obowiązujące w danym okresie dziejów placówki wizje stylu regionalnego czy narodowego i ludowości.

Choć w literaturze przedmiotu słusznie dostrzega się odmienny sposób czerpania z folkloru przez kolejnych dyrektorów placówki, trudno szukać krytycznego zreferowania ich stosunku do niego - opierającego się w dużej mierze na zawłaszczeniu, względach polityczno-ideowych i ekonomicznych. A przecież ludowość w ujęciu twórców związanych ze Szkołą Przemysłu Drzewnego w Zakopanem stanowiła właśnie konstrukt reprezentację sztuki góralskiej tworzoną przez elity artystyczne. Podhalańskie rzemiosło stające się obiektem fascynacji mieszczan pozornie zakrywało różnice klasowe, wytwarzając jednak z gruntu fałszywy dyskurs, obraz ludu pozbawiony kontekstu historycznego i materialnego.

Chęć „nauczania ludowości”, jaka od początku przyświecała szkole, u swoich podstaw naznaczona była paradoksem. Instytucjonalizacja zjawiska wykształconego naturalnie w obrębie ludu nie mogła zakończyć się odmiennie niż jego instrumentalizacją.
Im większą popularność zyskiwała ludowość, tym więcej podmiotów zabiegało o rolę w kształtowaniu jej wizerunku. Im bardziej atrakcyjne wizualnie stawało się jako koncept „Zakopane”, tym więcej zainteresowania wzbudzało - z lokalnej, zachowującej autentyzm tradycji bańki stając się pełnoprawnym uczestnikiem wczesnej globalizacji, unifikującej kultury jeszcze skuteczniej, niż austro-węgierskie wzorniki ludowych motywów. Ludowość w rękach zakopiańskich twórców była kategorią ideową, traktowaną utylitarnie, łączoną z bieżącymi tendencjami estetycznymi - jej postrzeganie i definicję opierano przede wszystkim na indywidualnych przekonaniach i odczuciach, którym towarzyszyły szersze interesy polityczno-rynkowe, zgodnie z tradycjami kolonialnymi. Poszukiwania ludowości w zakopiańskiej placówce przypadły na okres przemian w percepcji Podhala. Kraina, pod koniec XIX w. romantycznie mitologizowana, stała się na początku kolejnego stulecia ofiarą nadprodukcji różnorodnego „wyobrażonego" wizerunku jej dziedzictwa w postaci masowo wytwarzanych pamiątek.

W następstwie tych przemian „góralszczyzna" stała się konglomeratem skupionego na drewnie rzemiosła oraz wpływów i naleciałości, zapewnionych przez latami sterujących rozwojem lokalnej kultury „obcych". Odbiciem tego jest krajobraz współczesnego Zakopanego - tak miasta, jak i właściwej mu twórczości artystycznorzemieślniczej - przestrzeń wizualnego nieładu, czerpiącego z mnogości wzorów, jakie w świadomości ogólnej uchodzą za góralskie. Podhale, utożsamiane z kolebką polskości, na skutek procesu przemiany w kurort zostało wyrwane z własnej ludowości.

46 R. Gawrońska, Warsztat Augusta Zamoyskiego, w: August Zamoyski. Myśleć w kamieniu, [katalog wystawy, Muzeum Literatury], Warszawa 2019, s. $427-449$. 
STRESZCZENIE

\section{LUDOWOŚĆ UTRACONA? STRATEGIE \\ INSTYTUCJONALIZACJI SZTUKI \\ LUDOWEJ W SZKOLE PRZEMYSŁU \\ DRZEWNEGO W ZAKOPANEM}

W jakim stopniu funkcjonujące dzisiaj wyobrażenie „góralszczyzny” odpowiada tradycyjnej twórczości Podhala sprzed prób jej instytucjonalizacji? Tekst stanowi analizę metod konstruowania stylów regionalnego i narodowego, jakie realizowano w programach zakopiańskiej Szkoły Przemysłu Drzewnego z lat 1879-1939. Ówczesna twórczość rzeźbiarska wykładowców i wychowanków placówki oraz prowadzona w jej zakresie edukacja ukazują różnorodność prób instytucjonalizacji oraz instrumentalizacji ludowości. W literaturze przedmiotu brakuje jednak wyczerpującej analizy tych procesów. Celem tekstu jest prześledzenie (nad)użyć folkloru, do jakich dochodziło w obrębie uczelni. Analizie zostały poddane programy edukacji realizowane przez dyrektorów: Franciszka Neužila, Edgara Kovátsa, Stanisława Barabasza, Karola Stryjeńskiego oraz Adama Dobrodzickiego. Genealogia przywołanych koncepcji kształcenia ujawnia pewną ambiwalencję: nauczające wytwórczości ludowej programy były w rzeczywistości formami artystycznej ingerencji w regionalną kulturę Podhala, tworzonymi w większości przez „obcych” i dla „obcych”. Całość rozważań została zrealizowana z perspektywy studiów postkolonialnych oraz historii społeczno-politycznej.

\section{SŁOWA KLUCZOWE}

Szkoła Przemysłu Drzewnego, Zakopane, ludowość, styl regionalny, styl narodowy, studia postkolonialne, historia społeczno-polityczna

\section{SUMMARY}

\section{THE LOST FOLKLORE? STRATEGIES OF INDUSTRIALIZATION OF FOLK ART IN SCHOOL OF WOOD INDUSTRY IN ZAKOPANE}

To what extent does the present image of Polish "highland culture" reflect the traditional art and craftsmanship of Podhale from before its institutionalization? This study offers an analysis of methods of creation of regional and national style, conducted at the School of Wood Industry in Zakopane from 1879 to 1939. Art and craft of students and professors and the educational methods demonstrate various attempts of institutionalization and instrumentalization of folklore. Literature on the subject lacks a thorough analysis of those processes. The object of this study was to trace the (ab)uses of folklore that happened on account of the School. Analyzed were the teaching programmes carried out by headmasters: Franciszek Neužil, Edgar Kováts, Stanisław Barabasz, Karol Stryjeński, and Adam Dobrodzicki. Those methods of education reveal an ambivalence: while officially teaching local folklore and craft, they were in fact a form of artistic interference with the regional culture of Podhale, by "strangers" and for "strangers". The text was based on postcolonial studies and socio-political history.

\section{KEYWORDS}

School of Wood Industry, Zakopane, folklore, regional style, national style, postcolonial studies, socio-political history 


\section{BIBLIOGRAFIA}

Barabasz Stanisław, Sztuka ludowa na Podhalu, cz. 1-2: Spisz i Orawa, LwówWarszawa 1928; cz. 3: Witów, LwówWarszawa 1930; cz. 4: Kościót w Dębnie, Lwów-Warszawa 1932.

Brzostek Błażej, Czy folklor wszedł do śródmieścia? O motywach ludowych w PRL-u, w: Polska - kraj folkloru? [katalog wystawy, Zachęta Narodowa Galeria Sztuki], Warszawa 2016, s. 16-27.

Chrudzimska-Uhera Katarzyna, Stylizacje i modernizacje. O rzeźbie i rzeźbiarzach w Zakopanem w latach 1879-1939, Warszawa 2013.

Chrudzimska-Uhera Katarzyna, Secesja w Zakopanem?, „Pamiętnik Sztuk Pięknych", 2015, nr 10, s. 341-346.

Crowley David, National Style and Nationstate. Design in Poland from the Vernacular Revival to the International Style, Manchester-New York 1992.

Czy sztuka dekoracyjna?, „Blok”, 1925, nr 10, s. 1.

Gandhi Leela, Teoria postkolonialna: wprowadzenie krytyczne, tłum. Jacek Serwański, Poznań 2008.

Gawrońska Roksana, Warsztat Augusta Zamoyskiego, w: August Zamoyski. Myśleć w kamieniu, [katalog wystawy, Muzeum Literatury], Warszawa 2019, s. 427-449.

Giełdoń-Paszek Agnieszka, Drewno a sprawa polska: wykorzystanie drewna w poszukiwaniu polskiego stylu narodowego, „Studia Artystyczne”, 2015, nr 3, s. 134.

Hapanowicz Piotr, Działalność Muzeum Techniczno-Przemysłowego w Krakowie i jego likwidacja w latach 1949-1950, „Zarządzanie w Kulturze”, t. 8, 2007, s. 43-62.

Kenarowa Halina, Od zakopiańskiej Szkoły Przemysłu Drzewnego do szkoły
Kenara. Studium z dziejów szkolnictwa zawodowo-artystycznego w Polsce, Kraków 1978.

Nacjonalizm w sztuce i historii sztuki 17891950, red. Dariusz Konstantynów, Robert Pasieczny, Piotr Paszkiewicz, Warszawa 1998.

Kędziora Tomasz, Zakopiańska Szkoła Przemysłu Drzewnego w latach 18761918, „Studia Historyczne”, t. 36, 1993 , z. 4 (143), s. 477-488.

Kluczewska-Wójcik Agnieszka, What Art Poland Needs: in Search of the Polish National Style at the Beginning of the 2oth Century, w: History of Art History in Central, Eastern, and South-East Europe, red. Jerzy Malinowski, Toruń, 2012, s. 149-154.

Korduba Piotr, Jak wymyślono „ludowość na handel" - czyli o popieraniu przemystu i sztuki ludowej w międzywojennej Polsce, „Artium Quaestiones”, 2012, nr 23, s. 59.

Korduba Piotr, Ludowość na sprzedaż. Towarzystwo Popierania Przemysłu Ludowego, Cepelia, Instytut Wzornictwa Przemysłowego, Warszawa 2013, s. 13.

Krupa Maciej, Mazik Piotr, Szpilka Kuba, Nieobecne miasto. Przewodnik po nieznanym Zakopanem, Wołowiec 2016.

Liwak Katarzyna, Eksperymenty Antoniego Buszka z twórcami ludowymi, w: Polskie szkolnictwo artystyczne. Dzieje-teoria-praktyka, red. Maria Poprzęcka, Warszawa 2005, s. 193-199.

Relacje Warszawa - Zakopane [katalog wystawy, Muzeum Rzeźby im. Xawerego Dunikowskiego - Oddział Muzeum Narodowego w Warszawie], Warszawa 2017.

Malinowski Kazimierz, Szkoła rzeźby w Zakopanem, „Arkady”, 1937, nr 10, s. 544 . 
Mańkowski Bronisław, Zabawkarstwo w Polsce. Możliwość jego rozwoju na podstawie przykładów państw obcych, Warszawa 1920.

Nowakowska-Sito Katarzyna, W poszukiwaniu niepodległości w sztuce. Pawilon polski na wystawie paryskiej 1925, „Idea. Studia nad strukturą i rozwojem badań filozoficznych", t. 30, 2018, nr 1, s. 185-196.

Policht Piotr, Jak wymyślano podhalańską ludowość, 2019, culture.pl: https://cultu$\mathrm{re.pl} / \mathrm{pl} / \mathrm{artykul} / \mathrm{jak}$-wymyslano-podhalanska-ludowosc [dostęp 17 I 2020]

Szkolnictwo artystyczne, w: Polskie życie artystyczne w latach 1915-1939, red. Aleksander Wojciechowski, Wrocław-Warszawa-KrakówGdańsk 1974, s. 514-534.

Rzeźba w drewnie w twórczości polskich artystów 1918-2018 [katalog wystawy, Miejska Galeria Sztuki im. Władysława hr. Zamoyskiego], Zakopane 2018.

Skrzypczak Jerzy, Styl zakopiański w twórczości Tadeusza Stryjeńskiego, „Rocznik Podhalański”, t. 10, 2007, s. 105-126.

Stobiecka Monika, Kolonialny regionalizm. Problem tożsamości w zakopiańskiej architekturze, „Miejsce” 2019, nr 5 , https://www.doi.org/10.48285/8kaerzco3p [dostęp 17 I 2021].
Stryjeński Karol, Szkoła przemysłu drzewnego, „Giewont”, 1924, nr 1, s. 27.

Szczerski Andrzej, Cztery nowoczesności. Teksty o sztuce i architekturze polskiej XX wieku, Kraków 2015.

Szybisty Tomasz, «Sposób zakopański» i jego twórca Edgar Kováts (1849-1912), „Rocznik Podhalański”, t. 10 (za lata 2003-2006), 2007, s. 55-104.

Warchałowski Jerzy, O sztuce stosowanej, Kraków 1904, s. 4.

Warsztaty Krakowskie 1913-1926, red. Maria Dziedzic, Kraków 2009.

Witkiewicz Stanisław, Styl zakopiański, z. 1: Pokój jadalny, Lwów 1904.

Wystawa paryska 1925. Materiały z sesji naukowej Instytutu Sztuki PAN, red. J. Sosnowska, Warszawa 2007.

Żuber Agnieszka,Ikonografia cyklu grafik Bożki słowiańskie Zofii Stryjeńskiej, w: Polskie art déco. Materiały siódmej sesji naukowej „Polskie art déco. Malarstwo i grafika" pod przew. prof. Anny Sieradzkiej, prof. Andrzeja K. Olszewskiego i dr Anny Kostrzyńskiej-Miłosz w Muzeum Mazowieckim w Płocku 23-24 października 2017 roku, red. Zbigniew Chlewiński, Płock 2017, s. 92-121. 